\title{
BELASTING OP TOEGEVOEGDE WAARDE: GEVOLGE VAN KLIËNTELOJALITEITS-PROGRAMTRANSAKSIES VIR VERSKAFFERS
}

\author{
Sophia Brink* \\ Universiteit Stellenbosch \\ sophiabrink@sun.ac.za
}

Ontvang: Mei 2013

Aanvaar: Augustus 2013

\begin{abstract}
TITLE: Value-added tax implications of client loyalty program transactions.

Client loyalty programmes are a common phenomenon in the South African market. Despite the fact that client loyalty programmes have been prevalent in South Africa since the 1980s, the South African Revenue Service has issued minimal guidance on the value-added tax treatment of client loyalty programme transactions. The main objective of the research was to determine whether South African client loyalty programme suppliers correctly account for client loyalty programme transactions for value-added tax purposes. In order to meet this objective, available local literature was analysed to determine the proposed value-added tax treatment of a client loyalty programme transaction. The proposed correct value-added tax treatment was compared with a survey circulated to a population of client loyalty programme suppliers in South Africa. The comparison indicated that in practice the Value-Added Tax Act 89 of 1991 is not always interpreted correctly. This incorrect tax treatment could result in financial loss to the client loyalty programme supplier as taxpayer.
\end{abstract}

Sleutelwoorde

Kliëntelojaliteitsprogramtransaksie, punte, myle, Wet op Belasting op Toegevoegde Waarde no. 89 van 1991 (BTW-wet)

*Ms Sophia Brink is a lecturer in the Department of Accounting, Stellenbosch University, South Africa. 


\section{INLEIDING}

'n Kliëntelojaliteitsprogram kan omskryf word as 'n program waarvolgens gratis punte of myle deur verbruikers geakkumuleer word op grond van die aankoop van goedere of dienste vanaf'n verskaffer. Die verbruiker kan dan hierdie punte of myle vir ' $n$ verskeidenheid kommoditeite (insluitend goedere, dienste of afslag op ' $n$ volgende aankooptransaksie) by ' $n$ verskaffer inruil (Liu, 2007:20). Die gewildheid van kliëntelojaliteitsprogramme neem geweldig toe (Travel wires, 2011) en meer as 100 verskaffers in Suid-Afrika maak reeds van hierdie programme gebruik (Conradie, 2011). Alhoewel kliëntelojaliteitsprogramme reeds sedert die 1980's in Suid-Afrika voorkom (Travel wires, 2011), het die Suid-Afrikaanse Inkomstediens (SAID) minimale leiding oor die hantering van belasting op toegevoegde waarde (BTW) van ' $n$ kliëntelojaliteitsprogramtransaksie uitgereik. Die enigste leiding kom voor in uitlegnota $4 \mathrm{l}$ en word baie spesifiek tot die dobbelbedryf beperk. Die omvang van literatuur rakende die BTW-hantering van kliëntelojaliteitsprogramme in Suid-Afrika is beperk. Bestaande literatuur fokus op die inkomstebelastinghantering van kliëntelojaliteitsprogramtransaksies en spesifiek op die belasbaarheid van voordele wat deur ' $n$ verbruiker ontvang is ingevolge ' $n$ kliëntelojaliteitsprogramtransaksie. Pretorius (2010:1-71), Andoh (2008:1-80), Jones (2009:1-2) en Clegg (2002:33-35) het ondersoek ingestel na die belasbaarheid van punte of myle wat deur die werknemer verdien word op grond van goedere of dienste wat deur die werkgewer aangekoop is. Brink en Viviers (2012) het op hul beurt weer ondersoek ingestel of die bestaande bepalings in die Inkomstebelastingwet en verwante regspraak 'n basis bied vir die belasbaarheid van kliëntelojaliteitsprogramvoordele wat ontvang is in die hande van die verbruiker as natuurlike persoon. Uit bogenoemde literatuur het dit duidelik geblyk dat daar steeds ' $n$ gaping voorkom in die ondersoek rakende die BTW-hantering deur die verskaffer van 'n kliëntelojaliteitsprogramtransaksie.

\section{DOELWIT, METODOLOGIE EN WAARDE VAN NAVORSING}

Die doelwit van hierdie artikel was om te bepaal of die verskaffer van ' $n$ kliëntelojaliteitsprogramtransaksie dit korrek vir BTW-doeleindes verantwoord. Die omvang van die artikel word beperk tot die BTW-hantering van 'n kliëntelojaliteitsprogramtransaksie deur die verskaffer en gevolglik word die BTW-hantering deur die verbruiker nie bespreek nie. In die uitvoering van hierdie studie is daar verder besluit om die omvang van die studie te beperk tot hoofoperateursprogramme, aangesien dit ' $n$ loodsstudie was en die omvang andersins te wyd sou wees. Nog ' $n$ rede vir hierdie besluit was die feit dat die inligting (spesifiek die ledetal per program) ten opsigte van hierdie programme geredelik beskikbaar was ingevolge Conradie se studie (verwys na punt 6). Die hoofoperateurs van 'n kliëntelojaliteitsprogram tree op as die fasiliteerders van die kliëntelojaliteitsprogram. Sommige entiteite bied deelname aan ' $n$ kliëntelojaliteitsprogram waar die genoemde entiteit nie self die hoofoperateur van die kliëntelojaliteitsprogram is nie. ' $n$ Voorbeeld hiervan is Standard Bank wat hul kredietkaartgebruikers deelname aan SAA Voyager bied. Standard Bank tree hier slegs as 'n vennoot op en nie as die hoofoperateur nie. Standard Bank is dus nie ' $n$ hoofoperateurprogram nie (Conradie, 2007:13) en word van die omvang van die studie uitgesluit. Ten einde hierdie doelwit te bereik, is beskikbare literatuur ontleed om te bepaal wat die voorgestelde BTWhantering van ' $n$ kliëntelojaliteitsprogramtransaksie behels. Die voorgestelde BTW-hantering is vergelyk met die data wat deur vraelyste ingesamel is en wat aan ' $n$ populasie van kliëntelojaliteitsprogramverskaffers in Suid-Afrika versprei is. Die vergelyking dui aan of en in 
watter mate kliëntelojaliteitsprogramverskaffers ' $n$ kliëntelojaliteitsprogramtransaksie korrek vir BTW-doeleindes verantwoord. Ten einde ' $n$ beter begrip van die werking van kliëntelojaliteitsprogramme te verkry, is ' $n$ seleksie van die gewildste kliëntelojaliteitsprogramme in Suid-Afrika gemaak en is hierdie onderskeie kliëntelojaliteitsprogramme se bepalings en voorwaardes ontleed. Met inagneming van die werking van kliëntelojaliteitsprogramme, is die BTW-hantering van kliëntelojaliteitsprogramtransaksies in die hande van die verskaffer ontleed deur na relevante BTW-wetsartikels asook regspraak te verwys. BTW word in die rekeningkundige rekords verantwoord en die invloed van die Internasionale Finansiële Verslagdoeningstandaarde (IFRS) is kortliks oorweeg. Gegewe die gewildheid van kliëntelojaliteitsprogramme in SuidAfrika, tesame met die geweldige hoë randwaarde wat daarmee gepaardgaan (Travel wires, 2011 ), is dit belangrik om kliëntelojaliteitsprogramtransaksies op ' $n$ korrekte wyse vir BTWdoeleindes te hanteer.

\section{NAVORSINGSPROBLEEM}

Die BTW-wet word nie altyd korrek geïnterpreteer en toegepas nie, wat tot gevolg het dat ' $n$ BTWondernemer insetbelasting of uitsetbelasting verkeerdelik kan verantwoord. Indien ' $n$ BTWondernemer verkeerdelik nie uitsetbelasting verantwoord nie, sal hy in werklikheid die betaling van belasting ontduik, wat op ' $n$ misdryf dui ingevolge artikel 59 van die BTW-wet. Artikel 59 bepaal dat as ' $n$ persoon aan ' $n$ misdryf skuldig is ingevolge die BTW-wet, hy beboet sal word of gevangenisstraf van tot 60 maande opgelê kan word. Indien 'n BTW-ondernemer BTW ontduik, bepaal artikel 60 dat die SAID addisionele belasting van tot $200 \%$ kan hef op die BTW wat ontduik is. Rente kan ook op die aanvanklike onderbetaling én genoemde addisionele belasting gehef word. Onkunde is nie ' $n$ verweer nie en ingevolge artikel 59(2) van die BTW-wet word vermoed, totdat die teendeel bewys word, dat daardie persoon ' $n$ valse inskrywing met opset gedoen het om belasting te vermy.

\section{DIE WOORDOMSKRYWING EN WERKING VAN KLIËNTELOJALITEITS- PROGRAMME}

In artikel 1 van die Wet op Verbruikersbeskerming no. 68 van 2008 word die term 'lojaliteitsprogram' soos volg omskryf:

'n reëling of skema in die gewone loop van besigheid ingevolge waarvan 'n verskaffer van goedere of dienste ... enige lojaliteitskrediet of -toekenning in verband met 'n transaksie of 'n ooreenkoms aan 'n verbruiker aanbied of verleen...

Die basiese werking van kliëntelojaliteitsprogramme is soos volg: Lede van die algemene publiek kan aansoek doen om lidmaatskap te verkry deur ' $n$ aansoekvorm te voltooi waarop persoonlike inligting verstrek word. Goedgekeurde lede sal 'n lidmaatskapkaart ontvang wat tydens elke aankooptransaksie getoon moet word ten einde punte of myle te akkumuleer. ' $n$ Magnetiese strook op die agterkant van die lidmaatskapkaart sal die besonderhede van die items wat aangekoop is tesame met die punte of myle wat daarvoor toegeken word, versamel (Maharaj, 2008:12). Die punte of myle wat op die lidmaatskapkaart geakkumuleer word, kan later, tydens ' $n$ volgende aankooptransaksie, vir goedere, dienste of ' $n$ afslag op goedere of dienste ingeruil word. 


\section{KLIËNTELOJALITEITSPROGRAMME IN DIE SUID-AFRIKAANSE MARK}

Kliëntelojaliteitsprogramme in die Suid-Afrikaanse mark kan volgens die rol wat die eienaar van die program speel in drie verskillende kategorieë ingedeel word: ' $n$ enkelmaatskappyprogram, ' $n$ enkelmaatskappy-gedomineerde program en ' $n$ multivennootprogram (Conradie \& Goldstuck, 2005:12). ' $n$ Enkelmaatskappyprogram word gekenmerk deur die feit dat ' $n$ enkele eienaar (die verskaffer) die program bestuur en bedryf. Hierdie enkele eienaar is gevolglik self verantwoordelik vir die toekenning van punte of myle en ook vir die lewering van goedere, dienste of afslag met die inruil van punte of myle (Conradie \& Goldstuck, 2005:12). ' Enkelmaatskappy-gedomineerde program word gekenmerk deur die feit dat ' $n$ enkele eienaar die program bestuur en bedryf, maar dit is ' $n$ meer uitgebreide program waar ' $n$ groot aantal programvennote kan voorkom. Ingevolge hierdie program kan punte of myle by die programeienaar of enige van die programvennote verdien word en by die programeienaar of enige van die programvennote ingeruil word. Dit beteken dat die punte of myle nie net by die programeienaar ingeruil hoef te word nie. Alhoewel meer as een programvennoot in hierdie tipe program betrokke kan wees, sal die programeienaar steeds die hoofverskaffer van punte of myle en goedere, dienste of afslag wees (Conradie \& Goldstuck, 2005:12). 'n Multivennootprogram word gekenmerk deur die feit dat ' $n$ entiteit wat onafhanklik van al die programvennote is die program bestuur en bedryf. Hierdie entiteit vervul die rol van ' $n$ onafhanklike operateur of ' $n$ fasiliteerder wat slegs die onderskeie programvennote binne een program aan mekaar koppel. Die onafhanklike entiteit verskaf geen goedere of dienste buiten die kliëntelojaliteitsprogram self nie. Ingevolge hierdie program kan punte of myle by enige van die programvennote verdien word en ook by enige van die programvennote ingeruil word (Conradie \& Goldstuck, 2005:12-13). Sommige multivennootprogramme fasiliteer ' $n$ verskeidenheid kliëntelojaliteitsprogramme. $\varepsilon l k$ van hierdie kliëntelojaliteitsprogramme funksioneer egter afsonderlik en punte of myle word by 'n programvennoot verdien en ook ingeruil.

\section{SદLEKSIE VAN KLIËNTELOJALITEITSPROGRAMME VIR VERDERE ONDERSOEK}

Conradie het tussen 2003 en 2007 omvattende studies van kliëntelojaliteitsprogramme in SuidAfrika onderneem ter beoordeling van die waarde wat sodanige programme aan hulle lede bied. Die kontantwaarde (bereken as ' $n$ persentasie van kontant terug op werklike besteding), die verskeidenheid in voordeelkeuse en die gebruikersvriendelikheid van die kliëntelojaliteitsprogramme is van die faktore wat oorweeg is ten einde hierdie waarde te bepaal (Conradie, 2007:12; Conradie \& Goldstuck, 2005:13; Conradie \& Goldstuck, 2003:8). Gebaseer op die verslag soos wat deur Conradie (2007:1-283) saamgestel is, is ' $n$ populasie van kliëntelojaliteitsprogramverskaffers geselekteer deur na die volgende vereistes te verwys: Die kliëntelojaliteitsprogram moet ' $n$ tegnologies gedrewe hoofoperateursprogram wees, wat nasionaal aan die algemene publiek beskikbaar is, voor 1 Maart 2007 bekendgestel is en moet aankope as aansporingsfokus hê. Sewe-en-twintig kliëntelojaliteitsprogramme het aan hierdie vereistes voldoen en het gevolglik die populasie verteenwoordig. Die gewildste kliëntelojaliteitsprogramme, gebaseer op die bekende aktiewe ledegetalle, is geselekteer vanuit hierdie populasie om deel te vorm van die steekproef. Die populasie is gestratifiseer op grond van die rol wat die programeienaar speel asook die tipe nywerheidsektor waarin die kliëntelojaliteitsprogram bestaan. Die seleksie is uitgebrei deur ' $n$ verdere twee kliëntelojaliteits- 
programme te selekteer om te verseker dat die steekproef verteenwoordigend was van al die rolle wat die programeienaar speel, asook al die nywerheidsektore. TABEL 1 bevat die sewe geselekteerde kliëntelojaliteitsprogramme, die bekende aktiewe ledetal per program, asook die persentasie van die totale bekende aktiewe ledetal. Die seleksie het ' $n$ dekking van $78,9 \%$ van die populasie verseker.

TABEL 1: Geselekteerde kliëntelojaliteitsprogramme, die bekende aktiewe ledetal per program asook die persentasie van die totale bekende aktiewe ledetal

\begin{tabular}{lcc}
\hline $\begin{array}{c}\text { Kliëntelojaliteitsprogramme } \\
\text { geselekteer }\end{array}$ & Bekende aktiewe ledetal & $\begin{array}{c}\text { Persentasie van die totale } \\
\text { bekende aktiewe ledetal }\end{array}$ \\
\hline Clicks Club card & 2100000 & $24,4 \%$ \\
eBucks & 1100000 & $12,8 \%$ \\
Edgars Purple Cash Card & 1080000 & $12,5 \%$ \\
SAA Voyager & 890000 & $10,3 \%$ \\
Dis-Chem Benefit Programme & 750000 & $8,7 \%$ \\
Sun International Most Valued Guest & 505000 & $5,9 \%$ \\
Discovery Card Vitality & 374000 & $4,3 \%$ \\
Totale bekende aktiewe ledetal & 8624400 & $78,9 \%$ \\
Dekking & & \\
\hline
\end{tabular}

Bron: Conradie, 2007:135-235

Gegewe bostaande persentasie kan daar met ' $n$ redelike mate van sekerheid aangevoer word dat dit wesenlik die bepalings en voorwaardes van kliëntelojaliteitsprogramme in die SuidAfrikaanse mark verteenwoordig.

\section{BEPALINGS EN VOORWAARDES VAN KLIËNTELOJALITEITSPROGRAMME}

Die bepalings en voorwaardes van geselekteerde kliëntelojaliteitsprogramme is ondersoek ten einde grondige kennis te verkry oor die funksionering van kliëntelojaliteitsprogramme in die Suid-Afrikaanse mark. Hierdie kennis is noodsaaklik aangesien die verskillende eienskappe van elke program die BTW sowel as die uiteindelike rekeningkundige verantwoording van die transaksie beïnvloed. Die mees kenmerkende eienskappe in die bepalings en voorwaardes van kliëntelojaliteitsprogramme binne die verskillende industrieë is vervaldatums; die bepaalbaarheid van die waarde van punte of myle; die vorm waarin punte of myle ontvang word (kontant kan uitbetaal word, ' $n$ kontantterugbewys kan uitgereik word of punte of myle kan op die lidmaatskapkaart akkumuleer); die toegang tot geakkumuleerde punte of myle en op wie die verpligting rus om voordele te lewer. Ter verduideliking van laasgenoemde kan die verpligting om voordele te lewer op die programeienaar (verskaffer) of op 'n programvennoot (derde party) rus. Indien die programvennoot voordele lewer, sal die programeienaar, wat die punte of myle oorspronklik toegeken het, daarvoor verantwoordelik wees om 'n vergoeding aan die programvennoot te betaal in ruil vir die lewering van voordele. 


\section{ONTLEDING VAN WETGEWING OOR SUID-AFRIKAANSE BELASTING OP TOEGEVOEGDE WAARDE}

\subsection{BTW-gevolge vir die programeienaar (verskaffer)}

Ingevolge artikel 7 van die BTW-wet moet alle ondernemers wat vir BTW geregistreer is, uitsetbelasting teen $14 \%$ hef op die waarde van die goedere en dienste wat gelewer word. Die rekeningkundige basis wat deur ' $n$ onderneming gebruik word, bepaal die tyd van lewering vir $B T W$-doeleindes. Daar is twee rekeningkundige basisse wat deur ' $n$ ondernemer toegepas kan word: die faktuurbasis en die betalingsbasis.

Volgens artikel 15 van die BTW-wet kan ' $n$ ondernemer op die betalingsbasis vir BTW rekenskap gee indien: die ondernemer ' $n$ openbare bestuurder is; ' $n$ munisipaliteit of ' $n$ munisipale entiteit is wat elektrisiteit, gas, water, dreinering, of dienste wat met die verwydering van vullis of riool verband hou, lewer; ' $n$ vereniging sonder winsoogmerk is; enige Waterraad of ander instelling is wat soortgelyke magte as ' $n$ Waterraad het; ' $n$ plaaslike elektrisiteitsverspreider is; of die ondernemer ' $n$ natuurlike persoon of ' $n$ oningelyfde liggaam van persone is wie se lede almal natuurlike persone is, en die totale waarde van die belasbare lewerings in ' $n$ twaalfmaandetydperk nie R2,5 miljoen (BTW ingesluit) oorskry of moontlik sal oorskry nie; en die ondernemer skriftelik by die Kommissaris aansoek doen.

Nie een van die kliëntelojaliteitsprogramme wat vir die doeleindes van hierdie artikel ondersoek is (verwys na punt 5) voldoen aan bostaande vereistes nie en sal gevolglik op die faktuurbasis vir BTW rekenskap gee. Die tyd van lewering ingevolge die faktuurbasis is die vroegste van die datum waarop die faktuur uitgereik is of die datum waarop betaling van die vergoeding deur die leweraar ontvang word (artikel 9(1) van die BTW-wet). Artikel 10(23) van die BTW-wet bepaal dat indien 'n lewering teen geen vergoeding gemaak word nie, word die waarde van die lewering geag nul te wees.

Ingevolge kliëntelojaliteitsprogramme word goedere of dienste nie net tydens die oorspronklike verkooptransaksie gelewer nie, maar ook wanneer die punte of myle of kontantterugbewyse uiteindelik ingeruil word. Die vraag ontstaan of die lewering van goedere of dienste en die uiteindelike lewering van voordele as ' $n$ enkele transaksie of as twee afsonderlike transaksies beskou en hanteer moet word. Indien dit as ' $n$ enkele transaksie beskou word, sal dit vergelykbaar wees met afslag of korting toegestaan.

Op grond van ' $n$ gebrek aan plaaslike regspraak oor die onderwerp is beslissings in ander lande oorweeg ten einde bogenoemde vraag te beantwoord. In die Britse saak, Commissioner for HMRC $v$ Total Limited Court of Appeal [2007] ENHC 342, het die respondent, ' $n$ oliemaatskappy (T), 'n verkooppromosieskema aan verbruikers bekend gestel. Ingevolge die skema is punte en uiteindelik geskenkbewyse as voordele van ander handelaars ontvangbaar op grond van petrolaankope by T. T het vooraf die geskenkbewyse teen ' $n$ afslag van genoemde handelaars verkry om uiteindelik getroue verbruikers te beloon. Die kwessie in die saak was of die belasbare bedrag uit petrolverkope deur T, waarop uitsetbelasting betaalbaar is, verminder moet word met die waarde van die geskenkbewyse wat uitgereik is ingevolge die verkooppromosieskema. T het aangevoer dat in sover die skema vereis dat geskenkbewyse aan getroue petrolverbruikers gelewer word, die bedrag onderhewig aan uitsetbelasting nie die volle bedrag wat vir petrolverkope ontvang is, beloop nie. Volgens $T$ het die bedrag waarop uitsetbelasting gehef moet word, die petrolverkoopprys verminder met die koste om geskenkbewyse by die handelaars 
aan te koop. Thet verder geargumenteer dat wanneer geskenkbewyse aan die verbruiker vanweë petrolaankope oorgedra word, daar van ' $n$ bate afstand gedoen word en daarom sal die oordrag die vergoeding vir die lewering verminder en dus ook die belasbare uitsette verminder.

Die Britse Kommissaris het bevind dat die skema in wese ' $n$ kliëntelojaliteitsprogram verteenwoordig en nie net bloot ' $n$ afslagskema is nie. Die vergoeding wat T vir die verkoop van petrol ontvang, word nie geraak deur die voorsiening van geskenkbewyse ingevolge die skema nie. Die belastingpligtige se verkooppromosieskema dui nie op ' $n$ prysafslagskema nie en gevolglik moet die belasbare bedrag uit petrolverkope, wat aan uitsetbelasting onderhewig is, nie met die waarde van die geskenkbewyse wat aan getroue verbruikers uitgereik is, verminder word nie.

Die volgende is beslis: Die uitreiking van die geskenkbewys deur $\mathrm{T}$ het nie die oorspronklike vergoeding wat vir die lewering van petrol ontvang is, verminder nie. Die uitreiking van ' $n$ geskenkbewys kan nie as die toekenning van ' $n$ terugwerkende korting op die prys van petrol beskou word nie. Die partye se subjektiewe bedoeling en motiverings is buite rekening gelaat en die skema se dokumentasie het ' $n$ baie belangrike rol in die analise gespeel. Dit is gevolglik belangrik dat die skema se dokumentasie nie die uitreiking van die geskenkbewys as ' $n$ afslag of korting beskryf nie. In werklikheid het die verbruiker die volle pompprys vir die petrol betaal ongeag of die verbruiker ' $n$ lid was en punte verdien het en of die verbruiker nie ' $n$ lid was nie. Die verbruiker wat 'n geskenkbewys ontvang, verkry nie daardeur ' $n$ afslag of korting op die prys van die kwalifiserende aankope van petrol nie, maar verkry iets addisioneel bo en behalwe die petrol waarvoor betaal is. Ingevolge T se skema kon 'n verbruiker iets meer kry teen dieselfde prys, eerder as dieselfde teen ' $n$ laer prys. Die skema dui nie op ' $n$ prysafslagskema nie en die geskenkbewys moet nie as ' $n$ vermindering van vergoeding hanteer word nie. Die lewering van petrol en die uitreiking van ' $n$ geskenkbewys kan nie as ' $n$ enkele ekonomiese transaksie beskou word nie.

In die toepassing van bogenoemde op ' $n$ kliëntelojaliteitsprogramtransaksie geld die volgende: Die oorspronklike lewering van goedere of dienste ingevolge waarvan die punte of myle toegeken en/of kontantterugbewyse uitgereik word en die uiteindelike lewering van voordele, inruil vir punte of myle of kontantterugbewyse, moet as twee afsonderlike transaksies beskou en hanteer word. Die toekenning van die punte of myle en/of die uitreiking van kontantterugbewyse sal nie die oorspronklike vergoeding wat vir die goedere of dienste betaal is, beïnvloed nie. In werklikheid het die verbruiker die volle vergoeding vir die goedere of dienste betaal in die onderliggende aankooptransaksie ongeag of die verbruiker ' $n$ lid was en punte of myle verdien het (Commissioner for HMRC v Total Limited Court of Appeal [2007] ENHC 342). Die verbruiker betaal vergoeding vir die goedere of dienste en daar is geen sprake dat ' $n$ komponent van hierdie vergoeding betaal word vir die punte of myle nie. Die punte of myle word gevolglik vir belastingdoeleindes teen geen vergoeding verkry nie. Vir die drie kategorieë kliëntelojaliteitsprogramme (verwys na punt 5), sal die hantering van die twee komponente van die kliëntelojaliteitsprogramtransaksie verskil, gevolglik word die drie kategorieë afsonderlik oorweeg.

\subsection{BTW-effek op 'n enkelmaatskappyprogramtransaksie}

Ingevolge ' $n$ enkelmaatskappyprogram sal die programeienaar (verskaffer) altyd self verantwoordelik wees vir die toekenning van punte of myle of kontantterugbewyse en ook vir die uiteindelike lewering van voordele. Die BTW-effek op die twee komponente van ' $n$ enkelmaatskappyprogramtransaksie word hieronder uiteengesit. 
Wanneer goedere of dienste ingevolge ' $n$ kliëntelojaliteitsprogram deur ' $n$ BTW-ondernemer gelewer word, moet $14 \%$-uitsetbelasting op die volle verkoopprys van hierdie goedere of dienste (die waarde van die punte of myle wat toegeken is, uitgesluit) gehef word en aan die SAID oorbetaal word. Indien goedere of dienste in kontant verskaf word, sal die faktuurdatum en die datum van betaling waarskynlik ooreenstem en ook die tyd van lewering uitmaak. Indien goedere of dienste op krediet verskaf word, sal 'n faktuur gewoonlik eers uitgereik word voor betaling plaasvind. Die tyd van lewering sal dan die faktuurdatum wees.

Komponent 2: Die lewering van voordele deur die programeienaar (verskaffer) waar punte of myle of kontantterugbewyse ingeruil word

Wanneer voordele deur ' $n$ BTW-ondernemer in ruil vir punte of myle of kontantterugbewyse gelewer word, wil dit voorkom of die lewering teen geen vergoeding plaasvind nie, aangesien die verbruiker nie vir die voordele in geld betaal nie. Vergoeding word in artikel l van die BTW-wet omskryf as enige betaling gemaak of wat gemaak moet word, hetsy in geld of andersins. Artikel 10 (3)(b) van die BTW-wet bepaal dat indien betaling in ' $n$ ander vorm as geld geskied, sal die waarde van die vergoeding die ope markwaarde van dit wat betaal of oorhandig is, verteenwoordig. Artikel 3 van die BTW-wet bepaal verder dat die ope markwaarde, die vergoeding bedra waarvoor daardie goedere of dienste in soortgelyke omstandighede verhandel kon word. Die ope markwaarde sluit uitsetbelasting in (artikel 3(b) van die BTW-wet).

Ingevolge die tweede komponent van ' $n$ kliëntelojaliteitsprogramtransaksie geskied betaling in ' $n$ ander vorm as geld, naamlik in punte of myle of kontantterugbewyse wat deur die verbruiker vir voordele ingeruil word. Die ope markwaarde van die punte of myle of kontantterugbewyse wat ingeruil is, kan bepaal word deur te verwys na die bedrag (BTW ingesluit) van die voordele wat gelewer word of die waarde gekoppel aan die punte of myle of kontantterugbewyse wat ingeruil is. Die uitsetbelasting wat by die vergoeding ingesluit is, moet aan die SAID oorbetaal word. ' $n$ Faktuur sal uitgereik word wanneer die punte of myle of kontantterugbewyse ingeruil word (vergoeding betaal word) vir goedere, dienste of afslag. Die faktuurdatum en die datum van betaling sal gevolglik ooreenstem en die tyd van lewering is wanneer die punte of myle of kontantterugbewyse (vergoeding) ingeruil word en die goedere of dienste gelewer word.

\subsection{BTW-effek op ' $n$ enkelmaatskappy-gedomineerde program- transaksie}

' $n$ Enkelmaatskappy-gedomineerde program word deur ' $n$ enkele eienaar bestuur en ' $n$ verskeidenheid programvennote kan voorkom. Ingevolge hierdie program kan punte of myle of kontantterugbewyse by die programeienaar (verskaffer) of enige van die programvennote verdien en ingeruil word.

\section{Komponent 1: Die oorspronklike lewering van goedere of dienste}

Die BTW-effek op die oorspronklike lewering van goedere of dienste deur die programeienaar van ' $n$ enkelmaatskappy-gedomineerde program sal ooreenstem met dié van ' $n$ enkelmaatskappyprogram soos reeds bespreek is (verwys na punt 8.2, Komponent 1: Die oorspronklike lewering van goedere of dienste). Die geselekteerde kliëntelojaliteitsprogramme is beperk tot hoofoperateursprogramme (verwys na punt 2 en 5), met ander woorde slegs die programeienaar se BTW-gevolge word ondersoek. Verbruikers kan wel ingevolge hierdie program punte of myle 
verdien op grond van aankope vanaf die programvennote, maar die verantwoording deur die programvennote val buite die omvang van die artikel en word gevolglik nie bespreek nie.

Komponent 2: Die lewering van voordele deur die programeienaar (verskaffer) of deur 'n programvennoot (derde party)

Ingevolge ' $n$ enkelmaatskappy-gedomineerde program waar ' $n$ verskeidenheid programvennote voorkom, het die verbruiker ' $n$ opsie om punte of myle of kontantterugbewyse by die programeienaar of by ' $n$ programvennoot in te ruil. Indien die verbruiker punte of myle of kontantterugbewyse by die programeienaar inruil, sal die BTW-effek op die lewering van voordele ooreenstem met dié van 'n enkelmaatskappyprogram soos reeds bespreek (verwys na punt 8.2, Komponent 2: Die lewering van voordele deur die programeienaar (verskaffer) waar punte of myle of kontantterugbewyse ingeruil word). Indien die verbruiker punte of myle of kontantterugbewyse by 'n programvennoot inruil, sal die programeienaar nie die voordele lewer nie, maar vergoeding aan die programvennoot betaal vir die lewering van die voordele. Die vraag ontstaan of insetbelasting deur die programeienaar geëis kan word op grond van die vergoeding wat aan die programvennoot betaal word.

Ingevolge artikel 17 van die BTW-wet kan insetbelasting geëis word ten opsigte van alle betalings wat deur ' $n$ BTW-ondernemer gemaak is vir goedere en dienste wat by ' $n$ ander BTWondernemer aangekoop is wat vir die maak van belasbare lewerings gebruik gaan word. Belasbare lewerings word in artikel $l$ van die BTW-wet gedefinieer en lees soos volg:

' $n$ lewering van goed of dienste wat ingevolge die bepalings van artikel 7(1)(a) aan belasting onderhewig is, met inbegrip van belasting wat teen die skaal van nul persent ingevolge artikel 11 hefbaar is.

Artikel 7(1)(a) van die BTW-wet handel oor die heffing van uitsetbelasting en lees soos volg:

... word daar ten bate van die Nasionale Inkomstefonds 'n belasting gehef en betaal, bekend as die belasting op toegevoegde waarde-

(a) op die lewering deur ' $n$ ondernemer van goed of dienste wat op of na die aanvangsdatum deur hom gelewer word in die loop of ter bevordering van ' $n$ onderneming deur hom bedryf

Die derde party sal as ' $n$ programvennoot tot ' $n$ kliëntelojaliteitsprogram toetree ten einde volgehoue klandisie te verbeter. Die diens, naamlik die lewering van voordele in ruil vir punte of myle toegeken of kontantterugbewyse uitgereik, word gelewer in die loop of ter bevordering van die programvennoot se onderneming. Indien die programvennoot ' $n$ BTW-ondernemer is en voordele lewer, sal die uitsetbelasting wat ingesluit is by die vergoeding (bedrag (BTW ingesluit) van die voordele wat gelewer word) aan die SAID oorbetaal moet word. Die programvennoot sal uitsetbelasting hef op die diens wat gelewer word, naamlik die lewering van voordele in ruil vir punte of myle toegeken of kontantterugbewyse uitgereik. Die BTW-hantering deur die programvennoot stem gevolglik ooreen met die hantering deur die verskaffer soos reeds bespreek in punt 8.2, Komponent 2: Die lewering van voordele deur die programeienaar (verskaffer) waar punte of myle of kontantterugbewyse ingeruil word. Die uitsetbelastingverpligting van die programvennoot teenoor die SAID word in werklikheid oorgedra aan die programeienaar en die programvennoot tree bloot as die middelman op. Indien die programeienaar ook ' $n$ BTW-ondernemer is, sal die BTW (ingesluit by die vergoeding) wat gehef is en aan die programvennoot betaal is, van die SAID teruggeëis kan word. Die tyd van lewering is die vroegste van die datum waarop die faktuur deur die programvennoot uitgereik is of die datum waarop die vergoeding aan die programvennoot betaal word. Die faktuur sal 
gewoonlik eers uitgereik word voor betaling plaasvind. Die tyd van lewering sal dan die faktuurdatum wees.

Finansiëledienste- of kredietkaart-kliëntelojaliteitsprogramme kan gekategoriseer word as ' $n$ enkelmaatskappy-gedomineerde program. 'n Finansiëledienstekliëntelojaliteitsprogramtransaksie wyk grootliks af van bogenoemde standaardenkelmaatskappy-gedomineerde programtransaksie (verwys na punt 6 waar die bepalings en voorwaardes van geselekteerde kliëntelojaliteitsprogramme ondersoek is ten einde diepgaande kennis te verkry oor die funksionering van die programme). Daar is besluit om finansiëledienstekliëntelojaliteitsprogramme van die omvang van die studie uit te sluit, aangesien dit 'n loodsstudie was en die omvang van die studie andersins te wyd sou wees. Verwys na punt $l 1$ vir die uitsluiting van finansiëledienstekliëntelojaliteitsprogramme van die populasie.

\subsection{BTW-effek op 'n multivennootprogramtransaksie}

' $n$ Multivennootprogram word bestuur deur ' $n$ onafhanklike operateur of ' $n$ fasiliteerder. Twee tipes multivennootprogramme kom voor: ' $n$ kliëntelojaliteitsprogram wat afsonderlik funksioneer met net een programvennoot en ' $n$ kliëntelojaliteitsprogram met ' $n$ verskeidenheid programvennote. Ingevolge eersgenoemde program kan punte of myle by die enkele programvennoot verdien en ingeruil word. Wanneer die programvennoot punte of myle toeken, sal die programvennoot as fasiliteerder vergoeding (bereken as ' $n$ persentasie van die besteding) aan die programeienaar betaal vir die diens gelewer. Ingevolge die tweede genoemde program kan punte of myle by enige van die programvennote verdien en ook ingeruil word. Wanneer ' $n$ programvennoot punte of myle toeken, sal die programvennoot vergoeding betaal aan die programeienaar (fasiliteerder) en wanneer punte of myle by die programvennote ingeruil word, sal die programeienaar (fasiliteerder) vergoeding aan daardie programvennoot vir die lewering van voordele betaal.

\section{Komponent 1: Die oorspronklike lewering van goedere of dienste}

Die geselekteerde kliëntelojaliteitsprogramme is beperk tot hoofoperateursprogramme (verwys na punt 2 en 5), met ander woorde slegs die programeienaar (fasiliteerder) se BTW-gevolge word ondersoek. Verbruikers sal ingevolge hierdie program punte of myle verdien op grond van aankope by die programvennote. Die verantwoording deur die programvennote val buite die omvang van die artikel en word gevolglik nie bespreek nie. Die programeienaar sal vergoeding ontvang van die programvennote vir punte of myle wat toegeken is. Indien die programeienaar ' $n$ BTW-ondernemer is, sal BTW gehef word op die diens wat gelewer is as fasiliteerder van die kliëntelojaliteitsprogram, en hierdie uitsetbelasting wat ingesluit is in die vergoeding sal aan die SAID oorbetaal moet word. Die tyd van lewering is die vroegste van die datum waarop die faktuur deur die programeienaar uitgereik is of die datum waarop die vergoeding deur die programeienaar ontvang word. Die faktuur sal gewoonlik eers uitgereik word voor betaling plaasvind. Die tyd van lewering sal dan die faktuurdatum wees. Die BTW-gevolge is vir albei tipes multivennootprogramme dieselfde vir komponent een van die transaksie.

Komponent 2: Die programeienaar betaal vergoeding aan 'n programvennoot (derde party) vir die lewering van voordele

Verbruikers sal ingevolge hierdie program punte of myle of kontantterugbewyse slegs by die programvennote vir voordele inruil. Die verantwoording deur die programvennote val buite die omvang van die artikel en word gevolglik nie bespreek nie. Die geselekteerde 
kliëntelojaliteitsprogramme is beperk tot hoofoperateursprogramme (verwys na punt 2 en 5), met ander woorde slegs die programeienaar se BTW-gevolge word ondersoek. Die programeienaar sal vergoeding aan die programvennote betaal (ingevolge tweede genoemde program) vir die lewering van voordele. Die diens, naamlik die lewering van voordele in ruil vir punte of myle toegeken of kontantterugbewyse uitgereik, word gelewer in die loop of ter bevordering van die programvennoot se onderneming. Indien die programvennoot ' $n$ BTWondernemer is, sal uitsetbelasting gehef word op die diens wat gelewer word, naamlik die lewering van voordele in ruil vir punte of myle toegeken of kontantterugbewyse uitgereik. Indien die programeienaar ' $n$ BTW-ondernemer is, sal die insetbelasting teruggeëis kan word. Die tyd van lewering is die vroegste van die datum waarop die faktuur deur die programvennoot uitgereik is of die datum waarop die vergoeding deur die programeienaar betaal word. Die faktuur sal gewoonlik eers uitgereik word voor betaling plaasvind. Die tyd van lewering sal dan die faktuurdatum wees. Die tweede komponent van die transaksie kom slegs voor by tweede genoemde multivennootprogram waar' $n$ verskeidenheid van programvennote voorkom.

\subsection{Spesifieke leiding vanaf die SAID}

Die enigste spesifieke leiding vanaf die SAID ten opsigte van die BTW-hantering van kliëntelojaliteitsprogramtransaksies kom voor in uitlegnota 41 . Die doel van uitlegnota 41 is om duidelikheid te verskaf oor die BTW-implikasies van spesifieke transaksies in die dobbelbedryf en in paragraaf 4.2.4 word daar spesifiek verwys na die hantering van lojaliteitspunte. Ingevolge ' $n$ casinokliëntelojaliteitsprogram word verbruikers beloon vir lojaliteit in die vorm van lojaliteitspunte. Hierdie punte kan op hul beurt weer ingeruil word vir die plaas van verdere weddenskappe, vir maaltye by die casino se restaurante of by restaurante van ' $n$ derde party; of vir geld. Punte wat toegeken is op grond van ' $n$ weddenskap wat geplaas is, word as ' $n$ lewering ingevolge artikel 8(13) van die BTW-wet geag. Artikel 8(13) van die BTW-wet lees soos volg:

By die toepassing van hierdie Wet, waar 'n persoon 'n bedrag op die uitslag van 'n wedren of op enige ander gebeurtenis of voorval wed, word die persoon met wie die weddenskap aangegaan word, geag ' $n$ diens aan daardie eersgenoemde persoon te lewer.

Die ontvangs van weddenskapgeld word as ' $n$ lewering van ' $n$ diens geag (artikel 8(13)). ' $n$ Weddenskap word geag BTW in te sluit (artikel 10(17) van die BTW-wet) en casino's moet gevolglik uitsetbelasting op die weddenskapgeld wat ontvang is, verantwoord teen 14/114 van die totale weddenskapgeld wat ontvang is. Elke lewering word geag plaas te vind wanneer die weddenskap geplaas word (artikel 9(3)(e) van die BTW-wet) (Beneke 2012: par 5.12). Uitlegnota 41 bepaal dat die blote toekenning van die punte alleen geen BTW-gevolge het nie. Die BTWgevolge ontstaan eers wanneer die punte ingeruil word vir kontant of vir goedere of dienste. Die casino is gevolglik geregtig om insetbelasting ingevolge artikel $16(3)(d)$ van die BTW-wet te eis wanneer die punte ingeruil word. Artikel 16(3)(d) van die BTW-wet lees soos volg:

... die bedrag aan belasting wat ten opsigte van ' $n$ belastingtydperk betaalbaar is, bereken deur die totaal van die bedrae aan uitsetbelasting van die ondernemer wat aan daardie tydperk toeskryfbaar is ... die volgende bedrae af te trek, te wete-

(d) ' $n$ bedrag gelyk aan die belastingbreukdeel van ' $n$ bedrag wat deur die leweraar van die dienste beoog in artikel $8(13)$ as ' $n$ prys of wengeld aan die ontvanger van bedoelde dienste gedurende die belastingtydperk betaal is: Met dien verstande dat waar die prys of wengeld wat toegeken is bestaan uit óf goed óf dienste, die aftrekking beperk moet word tot die insetbelasting op die aanvanklike koste van verkryging van daardie goed of dienste. 
Indien die verbruiker die punte vir geld inruil, sal die casino daarop geregtig wees om insetbelasting te eis. Indien die verbruiker hierdie geld op ' $n$ volgende weddenskap plaas, sal die casino ingevolge artikel 8(13) van die BTW-wet uitsetbelasting moet verantwoord. Indien die verbruiker die punte verdien by ' $n$ programvennoot vir goedere of dienste inruil, sal die casino alleenlik insetbelasting kan eis met die ontvangs van ' $n$ belastingfaktuur van die programvennoot. Sonder die ontvangs van die belastingfaktuur sal die casino nie die insetbelasting kan bepaal nie, aangesien dit beperk word tot insetbelasting aangegaan met die oorspronklike verkryging.

Uitlegnota 41 bepaal dat met die toekenning van punte sal die casino ' $n$ uitgawe en ' $n$ las in die rekeningkundige rekords erken. Hierdie stelling is egter nie in ooreenstemming met die interpretasie van die International Financial Reporting Interpretations Committee (IFRIC) 13 nie. IFRIC 13 bepaal dat punte of myle toegeken as ' $n$ afsonderlike, identifiseerbare komponent van die kliëntelojaliteitsprogramtransaksie verantwoord moet word. Die billike waarde van die vergoeding ontvang of ontvangbaar ingevolge die aanvanklike verkoop moet tussen die punte of myle en die ander komponente van die verkooptransaksie toegedeel word. Die gedeelte wat aan die punte of myle toegeken is, sal eers as inkomste erken word wanneer die punte of myle ingeruil word en die erkenning van hierdie gedeelte van die inkomste word gevolglik uitgestel. Die uitgestelde inkomste voldoen aan die definisie van ' $n$ voorsiening vir rekeningkundige doeleindes (Brink, 2013). ' $n$ Voorsiening vir die lewering van goedere of dienste (las) word gevolglik geskep, maar geen uitgawe word erken nie. IFRIC 13 is uitgereik op 28 Junie 2007 en is van toepassing op jare wat op of na 1 Julie 2008 begin. Uitlegnota 41 (tweede uitreiking) gedateer 31 Maart 2008 vervang uitlegnota 41 (eerste uitreiking) gedateer 2 April 2007. Paragraaf 4.2.4 wat spesifiek hier van toepassing is, het nie verander in die tweede uitreiking van die uitlegnota nie. Die eerste weergawe is uitgereik voor IFRIC 13 en dit verduidelik dalk die foutiewe stelling. Dit blyk dat die paragraaf nie heroorweeg is met die tweede uitreiking nie en bevat gevolglik ' $n$ foutiewe stelling.

Die volgende voorbeelde word in uitlegnota 41 paragraaf 4.2.4 uiteengesit: Lucky is ' $n$ lid van Lady Luck casino se kliëntelojaliteitsprogram ingevolge waarvan hy 11400 punte op die blackjack-tafels verdien het (Lady Luck casino sou uitsetbelasting teen 14/114 van die oorspronklike weddenskap wat ontvang is aan die SAID moes oorbetaal). Lucky ruil die punte verdien in vir kontant ter waarde van R114. Lady Luck casino is geregtig om R14 (114 × 14/114) insetbelasting te eis ingevolge artikel 16(3)(h) van die BTW-wet. Lucky plaas ' $n$ weddenskap op die blackjack-tafels met die vergoeding wat ontvang is. Lady Luck casino moet ingevolge artikel 8(13) van die BTW-wet uitsetbelasting van R14 aan die SAID oorbetaal.

Lucky is ' $n$ lid van Lady Luck casino se kliëntelojaliteitsprogram ingevolge waarvan hy 11400 punte op die blackjack-tafels verdien het. Lucky ruil al die punte wat verdien is ter waarde van $R 114$ in vir ' $n$ maaltyd by ' $n$ restaurant (BTW-ondernemer), wat ' $n$ programvennoot van die kliëntelojaliteitsprogram is. Lady Luck casino ontvang ' $n$ belastingfaktuur van die restaurant en betaal die R114 verskuldig aan die restaurant. Lady Luck casino is geregtig om R14 (114 × 14/114) insetbelasting te eis ingevolge artikel 16(3)(h) van die BTW-wet.

Kliëntelojaliteitsprogramme in die dobbelbedryf kan gekategoriseer word as ' $n$ enkelmaatskappy-gedomineerde program. Die BTW-hantering van 'n kliëntelojaliteitsprogramtransaksie ingevolge uitlegnota 41 , saamgelees met artikel 8(13) en artikel 16(3)(h) van die BTW-wet wanneer punte ingeruil word op ' $n$ volgende weddenskap of wanneer punte ingeruil word by ' $n$ programvennoot, stem ooreen met die voorgestelde BTW-hantering van ' $n$ enkelmaatskappy-gedomineerde programtransaksie soos bespreek by punt 8.3. Hierdie 
ooreenstemming bied verdere ondersteuning vir die voorgestelde BTW-hantering soos reeds bespreek (verwys na punt 8.3). In TABEL 2 word hierdie ooreenstemming in 'n praktiese voorbeeld geïllustreer.

TABEL 2: Illustrasie van ooreenstemming tussen voorgestelde BTW-hantering en uitlegnota 41

\begin{tabular}{|c|c|c|}
\hline & Casino & Enkelmaatskappyprogram \\
\hline $\begin{array}{l}\text { Oorspronklike } \\
\text { aankooptransaksie }\end{array}$ & $\begin{array}{l}\text { 'n Weddenskap van Rl14 word by 'n } \\
\text { kliëntelojaliteitsprogram casino } \\
\text { geplaas. } \\
\text { BTW-gevolge vir die casino: } \\
\text { - Die casino moet ingevolge } \\
\text { artikel } 8 \text { (13) R14 (14/114 × } \\
\text { Rl14) se uitsetbelasting } \\
\text { verantwoord. }\end{array}$ & $\begin{array}{l}\text { Goedere van Rl14 (BTW ingesluit) } \\
\text { word vanaf 'n klientelojaliteits- } \\
\text { programverskaffer aangekoop. } \\
\text { BTW-gevolge vir die verskaffer: } \\
\text { - Die verskaffer moet } \mathrm{R} 14 \text { se } \\
\text { uitsetbelasting verantwoord } \\
\text { ( } 14 / 114 \times \mathrm{R} 114 \text { ), aangesien die } \\
\text { verkoop van die goedere die maak } \\
\text { van ' } n \text { belasbare lewering is. }\end{array}$ \\
\hline Toekenning van punte & $\begin{array}{l}\text { Punte met ' } n \text { randwaarde van R2 } \\
\text { word toegeken ingevolge die } \\
\text { transaksie. } \\
\text { BTW-gevolge vir die casino: } \\
\text { - Geen BTW-gevolge ontstaan met } \\
\text { die toekenning van punte nie } \\
\text { (uitlegnota } 41 \text { ). }\end{array}$ & $\begin{array}{l}\text { Punte met 'n randwaarde van R2 } \\
\text { word toegeken ingevolge die } \\
\text { transaksie. } \\
\text { BTW-gevolge vir die verskaffer: } \\
\text { - Geen BTW-gevolge ontstaan met } \\
\text { die toekenning van punte nie. }\end{array}$ \\
\hline Inruil van punte & $\begin{array}{l}\text { Die punte toegeken word vir R2- } \\
\text { kontant ingeruil wat dan op 'n } \\
\text { volgende weddenskap geplaas } \\
\text { word. } \\
\text { BTW-gevolge vir die casino: } \\
\text { - Die casino moet R0.25 (14/114 × } \\
\text { R2) se insetbelasting (artikel } \\
\text { l6(3)(h)) en R0.25 se } \\
\text { uitsetbelasting (artikel } 8(13)) \\
\text { verantwoord. }\end{array}$ & $\begin{array}{l}\text { Goedere van R2 (BTW ingesluit) word } \\
\text { ontvang met die inruil van die punte. } \\
\text { BTW-gevolge vir die verskaffer: } \\
\text { - Vergoeding in 'n ander vorm as } \\
\text { geld word ontvang en die } \\
\text { verskaffer moet R0.25 ( } 14 / 114 \times \\
\text { R2) se uitsetbelasting } \\
\text { verantwoord. }\end{array}$ \\
\hline
\end{tabular}

Bron: Outeur se analise

\subsection{Nulkoerslewerings}

Alle lewerings van goedere en dienste word teen ' $n$ standaardkoers van $14 \%$ belas, behalwe as dit teen nulkoers belas word of as dit spesifiek van belasting vrygestel is. Nulkoerslewerings is steeds belasbare lewerings wat beteken dat die BTW-ondernemer in staat is om alle insetbelasting met betrekking tot nulkoerslewerings te kan eis selfs al word uitsetbelasting teen $14 \%$ nie op die lewerings gevorder nie (Stiglingh, Koekemoer, Van Schalkwyk, Wilcocks \& De Swardt, 2012). Artikel 11 van die BTW-wet handel oor nulkoerslewerings. Die volgende nulkoerslewerings is spesifiek op kliëntelojaliteitsprogramtransaksies van toepassing: uitgevoerde dienste (vervoer) en sekere basiese voedselsoorte. 
Uitgevoerde dienste: vervoer

Artikel $11(2)(a)$ van die BTW-wet bepaal dat die vervoer van passasiers en goedere onderhewig is aan die nulkoers indien die vervoer geskied vanaf 'n plek buite Suid-Afrika na 'n ander plek buite Suid-Afrika, vanaf 'n plek in Suid-Afrika na 'n plek in 'n uitvoerland of vanaf 'n plek in 'n uitvoerland na 'n plek in Suid-Afrika. Uitsetbelasting sal gevolglik gehef word op ' $n$ vlug vanaf Kaapstad na Johannesburg, maar nie op ' $n$ vlug vanaf Kaapstad na Bangkok nie. Indien ' $n$ verbruiker ingevolge ' $n$ kliëntelojaliteitsprogramtransaksie uitgevoerde dienste soos omskryf, verkry, sal BTW teen $0 \%$ gehef word.

Twee gereelde vliegprogramme wat ingesluit was in die populasie van 27 kliëntelojaliteitsprogramme wat geselekteer is ingevolge die verslag wat deur Conradie (2007:1-283) saamgestel is (verwys na punt 6 vir seleksiekriteria van populasie), behartig slegs internasionale vlugte. Daar is besluit om hierdie twee gereelde vliegprogramme van die omvang van die studie uit te sluit ten einde ' $n$ enkele vraelys uit te stuur en hierdie vraelys so eenvoudig moontlik te hou (verwys na punt 11).

\section{Basiese voedselsoorte}

Deel $B$ van Bylae 2 tot die BTW-wet bevat ' $n$ lys van basiese voedselsoorte wat teen nulkoers belas word. Hierdie lys sluit onder meer die volgende in: bruinbrood, mieliemeel, stampmielies, mielierys, rys, sardyne, melk en melkpoeier, vars vrugte en groente, plantaardige olie (olyfolie uitgesluit), eiers en lensies. Indien ' $n$ verbruiker enige van hierdie basiese voedselsoorte ingevolge ' $n$ kliëntelojaliteitsprogramtransaksie verkry, sal BTW teen $0 \%$ gehef word.

\subsection{Punte of myle soortgelyk aan afslag of korting}

Punte of myle toegeken of kontantterugbewyse uitgereik, kan ook beskou word as voordele soortgelyk aan afslag of korting toegestaan (Rowley, 2005:195). Ingevolge afslag of korting toegestaan deur ' $n$ verskaffer, sal die verskaffer alleenlik uitsetbelasting verantwoord op die bruto bedrag (Beneke, 2012:par 4.3). Dit wil voorkom of die inruil van die punte of myle of kontantterugbewyse geen BTW-gevolge moet hê nie. In Commissioner for HMRC v Total Limited Court of Appeal [2007] ENHC 342 is egter beslis dat punte of myle toegeken of kontantterugbewyse uitgereik ingevolge ' $n$ kliëntelojaliteitsprogram vir BTW-doeleindes nie as afslag of korting beskou kan word nie (selfs nie eers wanneer die punte of myle of kontantterugbewyse ingeruil word nie).

\subsection{Punte of myle soortgelyk aan geskenkbewyse}

Punte of myle of kontantterugbewyse kan ook beskou word as ' $n$ reg op goedere of dienste wat soortgelyk is aan ' $n$ geskenkbewys. Die waarde van enige teken, geskenkbewys of seël wat vir goedere of dienste ingeruil kan word, word gereguleer deur artikel 10(18)-(20) van die BTW-wet. Artikel 10(18) en 10(19) handel oor die waarde van die lewering wanneer ' $n$ teken, geskenkbewys of seël teen vergoeding verkry word en artikel 10(20) handel oor wanneer die teken, geskenkbewys of seël teen geen vergoeding verkry word nie. Ten einde verdere ondersteuning te bied aan die bevinding dat die inruil van punte of myle of kontantterugbewyse wel uitsetbelastinggevolge het en wat die waarde daarvan beloop, word ' $n$ kliëntelojaliteitsprogramtransaksie volgens die vereistes van artikel 10(18)-(20) gemeet. 
In die toepassing van artikel 10(18)-(20) op kliëntelojaliteitsprogramtransaksies ontstaan die vraag of die punte of myle of kontantterugbewyse teen geen vergoeding verkry word nie en of ' $n$ komponent van die vergoeding ter verkryging van goedere of dienste nie toegedeel moet word aan die punte of myle of kontantterugbewyse nie. Die toekenning van die punte of myle en/of die uitreiking van kontantterugbewyse sal nie die oorspronklike vergoeding wat vir die goedere of dienste betaal is, beïnvloed nie. In werklikheid het die verbruiker die volle vergoeding vir die goedere of dienste betaal in die onderliggende aankooptransaksie ongeag of die verbruiker ' $n$ lid was en punte of myle verdien het en of die verbruiker nie ' $n$ lid was nie (Commissioner for HMRC $v$ Total Limited Court of Appeal [2007] ENHC 342). Vir belastingdoeleindes word die punte of myle of kontantterugbewyse teen geen vergoeding verkry nie en sal artikel 10(20) van die BTW-wet van toepassing wees.

Artikel 10(20) van die BTW-wet lees soos volg:

Waar ' $n$ teken, bewys of seël deur ' $n$ ondernemer teen geen vergoeding uitgereik word en die besitter daarvan geregtig is by die afgee daarvan aan ' $n$ ander persoon, wat die leweraar van die goedere of dienste is, op ' $n$ afslag op die prys van goed of dienste aan die besitter gelewer, word die vergoeding in geld vir die lewering van daardie goed of dienste geag die geldwaarde wat op bedoelde teken, bewys of seël vermeld word, in te sluit: Met dien verstande dat daardie geldwaarde geag word belasting in te sluit.

Die waarde, gekoppel aan die punte of myle of die waarde gestipuleer op die kontantterugbewys, word gevolglik beskou as vergoeding (BTW ingesluit) wat vir die goedere of dienste betaal is. Die verskaffer (BTW-ondernemer) by wie die verbruiker die punte of myle of kontantterugbewyse inruil, moet die uitsetbelasting wat by die vergoeding ingesluit is aan die SAID oorbetaal.

Artikel $10(20)$ vereis dat die punte of myle of kontantterugbewyse by ' $n$ ander persoon ingeruil moet word. Dit sal slegs die geval wees waar ' $n$ enkelmaatskappy-gedomineerde program of ' $n$ multivennootprogram voorkom en die verbruiker die punte of myle of kontantterugbewyse by een van die programvennote (ook ' $n$ BTW-ondernemer) inruil. Geen ander artikel in die BTW-wet maak voorsiening vir waar ' $n$ teken, geskenkbewys of seël teen geen vergoeding verkry word nie. Artikel 10(20) bied gevolglik verdere ondersteuning aan die bevinding dat die inruil van punte of myle of kontantterugbewyse wel uitsetbelastinggevolge het en dat hierdie waarde by die vergoeding ingesluit is.

\section{REKENINGKUNDIGE VERANTWOORDING VAN KLIËNTELOJALITEITS- PROGRAMTRANSAKSIES}

Ingevolge ' $n$ kliëntelojaliteitsprogram word punte of myle as deel van ' $n$ normale verkooptransaksie deur die programeienaar (verskaffer) aan die verbruiker toegeken, wat die verbruiker ' $n$ reg op toekomstige goedere, dienste of afslag (voordele) gee. Die punte of myle toegeken, beïnvloed gevolglik die werklike vergoeding wat die programeienaar vir rekeningkundige doeleindes ontvang vir die lewering van goedere of dienste ingevolge die onderliggende verkooptransaksie. Ten einde hierdie vergoeding te verantwoord, moet die programeienaar die rekeningkundige standpunt, International Accounting Standards (IAS) 18, wat oor die verantwoording van inkomste handel, oorweeg. In die verantwoording van ' $n$ kliëntelojaliteitsprogramtransaksie moet die interpretasie van IFRIC 13 Customer Loyalty Programmes toegepas word. 


\subsection{IFRIC 13 tesame met IAS 18}

IAS 18 handel oor die rekeningkundige hantering van inkomste uit die verkoop van goedere, die lewering van dienste of die generering van inkomste soos rente, tantième of dividende uit die gebruik van entiteitsbates. IAS 18 paragraaf 8 bepaal dat inkomste slegs die bruto-invloei van ekonomiese voordele deur die entiteit ontvang op eie rekening insluit. Bedrae wat namens derde partye ontvang word, soos byvoorbeeld BTW, word uitgesluit omdat dit nie op ekonomiese voordele wat na die entiteit vloei, dui nie en gevolglik nie tot ' $n$ toename in ekwiteit lei nie.

IFRIC 13 handel oor kliëntelojaliteitsprogramme en is van toepassing op punte of myle wat: deur ' $n$ entiteit aan verbruikers toegeken word as deel van ' $n$ verkooptransaksie; en onderhewig is aan verdere kwalifiserende voorwaardes, wat die verbruiker in staat stel om goedere of dienste in die toekoms gratis of teen afslag te eis (IFRIC 13, paragraaf 3). Die interpretasie handel oor die rekeningkundige hantering deur die verskaffer wat die punte of myle aan sy verbruikers toeken. Konsensus is bereik rakende onsekerhede oor die meting en erkenning van punte of myle toegeken en word in paragraaf 5 tot 8 in IFRIC 13 uiteengesit. Paragraaf 5 van IFRIC 13 bepaal dat paragraaf 13 van IAS 18 toegepas moet word ten einde die vergoeding wat ontvang is, te verantwoord. Paragraaf 13 van IAS 18 bepaal dat die erkenningsmaatstawwe van IAS 18 gewoonlik afsonderlik op elke transaksie toegepas word. In sommige omstandighede is dit nodig om die erkenningsmaatstawwe op elke afsonderlik identifiseerbare komponent van ' $n$ enkele transaksie toe te pas ten einde aan die wese van die transaksie uiting te gee. Byvoorbeeld: waar die verkoopprys van ' $n$ produk ' $n$ identifiseerbare bedrag vir daaropvolgende dienslewering insluit, sal hierdie bedrag as inkomste erken word oor die periode wat die diens gelewer word en die erkenning van ' $n$ gedeelte van die inkomste word gevolglik uitgestel. Ten spyte van die feit dat kliëntelojaliteitsprogramtransaksie as twee afsonderlike transaksies hanteer word vir BTWdoeleindes, kan dit, weens die voorafgaande voorbeeld beskou word as ' $n$ enkele transaksie wat uit twee afsonderlike identifiseerbare komponente bestaan vir rekeningkundige doeleindes: die verkope van goedere of dienste en die toekenning van punte of myle wat die verbruiker ' $n$ reg tot voordele gee.

Ingevolge paragraaf 13 van IAS 18 moet die erkenningsmaatstawwe op elkeen van die komponente toegepas word. Die punte of myle toegeken, is gekoppel aan ' $n$ identifiseerbare bedrag of waarde, naamlik die waarde van die voordele wat in die toekoms verkry kan word. Die verkoopprys sluit gevolglik ' $n$ identifiseerbare bedrag vir die toekomstige lewering van voordele in. ' $n$ Kliëntelojaliteitsprogramtransaksie is gevolglik soortgelyk aan die voorbeeld wat in paragraaf 13 van IAS 18 genoem is, naamlik ' $n$ verkooptransaksie waar die verkoopprys ' $n$ bedrag vir daaropvolgende dienslewering insluit. Die vergoeding ontvang of ontvangbaar uit die verkooptransaksie moet dus toegedeel word aan die goedere of dienste verkoop en aan die punte of myle toegeken. Die gedeelte wat toegedeel is aan die goedere of dienste wat verkoop is, sal tydens die verkooptransaksie as inkomste erken word. Die gedeelte wat aan die punte of myle toegedeel is, sal eers as inkomste erken word wanneer die punte of myle ingeruil word en die erkenning van hierdie gedeelte van die inkomste word gevolglik uitgestel.

IFRIC 13 paragraaf 5 bepaal voorts dat die billike waarde van die vergoeding ontvang of ontvangbaar ingevolge die aanvanklike verkoop tussen die punte of myle en die ander komponente van die verkooptransaksie toegedeel moet word. Paragraaf 6 van IFRIC 13 bepaal dat die gedeelte van die vergoeding wat aan die punte of myle toegeken in die onderliggende verkooptransaksie toegedeel word, gemeet kan word deur na die billike waarde te verwys. In die Toepassingsgids (Application Guidance) tot IFRIC 13 (wat as ' $n$ geïntegreerde deel van die vertolking beskou word) word daar spesifieke leiding verskaf oor die bepaling van die billike 
waarde. Die meting en erkenning van ' $n$ kliëntelojaliteitsprogramtransaksie ingevolge IFRIC 13 verskil waar die verpligting om voordele te lewer op die programeienaar rus en waar die verpligting om voordele te lewer op ' $n$ programvennoot (derde party) rus. Twee verskillende tipes kliëntelojaliteitsprogramme kom voor waar die verpligting om voordele te lewer op ' $n$ programvennoot rus: Die verpligting om voordele te lewer rus op die programeienaar of op ' $n$ programvennoot (die verbruiker het die opsie om punte of myle of kontantterugbewyse by die programeienaar of ' $n$ programvennoot in te ruil) en die verpligting om voordele te lewer rus op die programvennoot alleen (die verbruiker kan punte of myle of kontantterugbewyse slegs by ' $n$ programvennoot inruil).

Verpligting om voordele te lewer rus op die programeienaar

Paragraaf 7 van IFRIC 13 bepaal dat wanneer die verpligting om uiteindelik voordele te lewer op die programeienaar rus, moet ' $n$ gedeelte van die vergoeding aan die punte of myle toegedeel word en as inkomste erken word wanneer die punte of myle ingeruil word en die programeienaar sy verpligting om voordele te lewer, nakom. Hierdie bedrag van inkomste sal gebaseer word op die aantal punte of myle wat ingeruil word met betrekking tot die totale aantal punte of myle wat na verwagting uiteindelik ingeruil sal word. Die uitgestelde inkomste voldoen aan die definisie van ' $n$ voorsiening vir rekeningkundige doeleindes (Brink, 2013) en sal gevolglik as ' $n$ voorsiening vir die lewering van voordele erken word.

Verpligting om voordele te lewer rus op 'n programvennoot

Paragraaf 8 van IFRIC 13 bepaal dat wanneer ' $n$ programvennoot verantwoordelik is vir die lewering van voordele, moet die programeienaar bepaal of die vergoeding toegedeel aan die punte of myle namens homself (as prinsipaal van die transaksie) of namens ' $n$ programvennoot (as agent van die transaksie) ingevorder word.

Indien die vergoeding namens ' $n$ programvennoot ingevorder word, word kommissie verdien (PricewaterhouseCoopers, 2009). Die kommissie-inkomste moet gemeet word teen die netto bedrag wat vir eie voordeel behou word. Dit sal die verskil tussen die vergoeding aan die punte of myle toegedeel en die bedrag verskuldig aan 'n programvennoot vir die uiteindelike lewering van die voordele verteenwoordig. Hierdie kommissie (netto bedrag) moet erken word wanneer die programvennoot verplig word om voordele te lewer en geregtig word om vergoeding daarvoor te ontvang. Dit kan plaasvind sodra die punte of myle toegeken word (indien die verpligting om voordele te lewer op die programvennoot alleen rus). Anders, wanneer die verbruiker ' $n$ keuse het om die voordele vanaf die programeienaar of van 'n programvennoot te eis, sal bogenoemde net plaasvind wanneer die verbruiker sy keuse uitoefen om die voordele van die programvennoot te eis (IFRIC 13, paragraaf 8).

Indien die programeienaar vergoeding namens homself invorder, moet die inkomste gemeet word teen die bruto vergoeding wat aan die punte of myle toegedeel is. Die inkomste moet erken word wanneer die entiteit sy verpligting om die voordele te lewer, nakom (IFRIC 13, paragraaf 8). ' $n$ Element van hierdie inkomste moet gevolglik uitgestel word totdat die punte of myle ingeruil word of die punte of myle verval (PricewaterhouseCoopers, 2009).

' $n$ Enkelmaatskappyprogram sowel as ' $n$ enkelmaatskappy-gedomineerde program (indien die verbruiker punte of myle of kontantterugbewyse by die programeienaar inruil) sal gekategoriseer kan word as Verpligting om voordele te lewer, rus op die programeienaar. ' $\mathrm{n}$ Enkelmaatskappy-gedomineerde program (indien die verbruiker punte of myle of 
kontantterugbewyse by ' $n$ programvennoot inruil) en ' $n$ multivennootprogram sal gekategoriseer kan word as Verpligting om voordele te lewer rus op 'n programvennoot.

\subsection{Voorbeeld: volledige rekeningkundige inskrywings van kliëntelojaliteitsprogramtransaksies}

Eenvoudige voorbeelde om die BTW-effek op kliëntelojaliteitsprogramtransaksies te illustreer, word hieronder uiteengesit. IFRIC 13 dek meer gekompliseerde gebeurtenisse binne die verantwoording van ' $n$ kliëntelojaliteitsprogramtransaksie; byvoorbeeld as die bestuur se verwagting ten opsigte van die punte wat ingeruil gaan word, verander. $0 \mathrm{~m}$ die fokus nie na IFRIC 13 te verskuif nie, word die voorbeelde eenvoudig gehou.

\subsection{Voorbeeld: 'n enkelmaatskappyprogram-transaksie (verpligting om voordele te lewer rus op die programeienaar)}

' $n$ Kruidenierswarehandelaar bedryf ' $n$ enkelmaatskappy-kliëntelojaliteitsprogram. Punte toegeken akkumuleer op die lidmaatskapkaart en is nie aan ' $n$ vervaldatum onderhewig nie. Die kruidenierswarehandelaar het gedurende jaar een Rl 000 (BTW uitgesluit) se goedere kontant aan kliëntelojaliteitsprogramlede verkoop en 100 punte ter waarde van Rl.25 toegeken.

TABEL 3: Algemene joernaalinskrywings van die kruidenierswarehandelaar

\begin{tabular}{|c|c|c|c|}
\hline Datum & Joernaalinskrywing & Debiet & Krediet \\
\hline \multirow[t]{9}{*}{ Jaar 1} & Bank $(1000 \times 1,14)$ & 1140 & \\
\hline & Inkomste uit die verkoop van goedere & & 900 \\
\hline & Voorsiening vir die lewering van goedere & & 100 \\
\hline & BTW-kontrole $(1140 \times 14 / 114)$ & & 140 \\
\hline & $\begin{array}{l}\text { (Verantwoord uitset-BTW op die oorspronklike verkooptrans } \\
\text { vergoeding ontvang) }\end{array}$ & ssie teen & 14 van die \\
\hline & $\begin{array}{l}\text { Voorsiening vir die lewering van goedere ( } 40 \text { punte } / 80 \\
\text { punte } \times \text { R100) }\end{array}$ & 50 & \\
\hline & Inkomste uit die verkoop van goedere & & 43.86 \\
\hline & BTW-kontrole $(\mathrm{R} 50 \times 14 / 114)$ & & 6.14 \\
\hline & $\begin{array}{l}\text { (Verantwoord uitset-BTW op die inruiltransaksies teen } 1 \\
\text { ontvang) }\end{array}$ & 114 van & vergoeding \\
\hline \multirow[t]{4}{*}{ Jaar 2} & $\begin{array}{l}\text { Voorsiening vir die lewering van goedere ( } 40 \text { punte } / 80 \\
\text { punte } \times \text { R100) }\end{array}$ & 50 & \\
\hline & Inkomste uit die verkoop van goedere & & 43.86 \\
\hline & BTW-kontrole $($ R50 × 14/114) & & 6.14 \\
\hline & $\begin{array}{l}\text { (Verantwoord uitset-BTW op die inruiltransaksies teen } 1 \\
\text { ontvang) }\end{array}$ & 114 van & vergoeding \\
\hline
\end{tabular}

Bron: Outeur se analise 
Die bestuur verwag dat net 80 van die 100 punte wat toegeken is, ingeruil gaan word. Die billike waarde van die punte toegeken, kan gevolglik bereken word as R1 ( 80 punte / 100 punte $\times$ R1.25 $=\mathrm{R} 1$ ). Aan die einde van jaar een word 40 punte ingeruil en goedere ter waarde van R50 word gelewer. Ooreenkomstig die bestuur se verwagting word 40 punte gedurende jaar twee ingeruil en goedere ter waarde van R50 word gelewer. TABEL 3 illustreer die rekeningkundige inskrywings van bogenoemde transaksie in die algemene joernaal van die kruidenierswarehandelaar.

\subsection{Voorbeeld: 'n Enkelmaatskappy-gedomineerde programtransaksie (Verpligting om voordele te lewer rus op die programeienaar of op 'n programvennoot: Die verbruiker het die opsie om punte of myle by die programeienaar of ' $n$ programvennoot in te ruil)}

'n Lugredery bedryf ' $n$ enkelmaatskappy-gedomineerde kliëntelojaliteitsprogram. Myle toegeken akkumuleer op die lidmaatskapkaart en is nie aan ' $n$ vervaldatum onderhewig nie. Die verbruiker kan die myle by die lugredery of by ' $n$ programvennoot inruil. Indien myle by ' $n$ programvennoot ingeruil word, moet die lugredery die programvennoot R0.90 per myl ingeruil vergoed vir die lewering van voordele. Die lugredery het gedurende jaar een R1 000 (BTW uitgesluit) se dienste kontant aan kliëntelojaliteitsprogramlede verkoop en 100 myle ter waarde van $\mathrm{Rl}$ toegeken. Die bestuur verwag dat alle myle wat toegeken is, ingeruil gaan word. Die billike waarde van die myle toegeken, kan as Rl bereken word. Gedurende jaar twee word al 100 myle by die lugredery ingeruil en dienste word ooreenkomstig gelewer. Aanvaar dat alle dienste gelewer verband hou met plaaslike vlugte. TABEL 4 illustreer die rekeningkundige inskrywings van bogenoemde transaksie in die algemene joernaal van die lugredery.

TABEL 4: Algemene joernaalinskrywings van die lugredery

\begin{tabular}{|c|c|c|c|}
\hline Datum & Joernaalinskrywing & Debiet & Krediet \\
\hline \multirow[t]{5}{*}{ Jaar 1} & Bank $(1000 \times 1.14)$ & 1140 & \\
\hline & Inkomste uit die verkoop van dienste & & 900 \\
\hline & $\begin{array}{l}\text { Voorsiening vir die lewering van dienste / vir vergoeding } \\
\text { betaalbaar }\end{array}$ & & 100 \\
\hline & BTW-kontrole $(1140 \times 14 / 114)$ & & 140 \\
\hline & $\begin{array}{l}\text { (Verantwoord uitset-BTW op die oorspronklike verkooptransaksie } \\
\text { vergoeding ontvang) }\end{array}$ & e teen $14 / 1$ & 14 van die \\
\hline \multirow[t]{4}{*}{ Jaar 2} & $\begin{array}{l}\text { Voorsiening vir die lewering van dienste / vir vergoeding } \\
\text { betaalbaar }\end{array}$ & 100 & \\
\hline & Inkomste uit die verkoop van goedere & & 87.72 \\
\hline & BTW-kontrole $(\mathrm{R} 100 \times 14 / 114)$ & & 12.28 \\
\hline & $\begin{array}{l}\text { (Verantwoord uitset-BTW op die inruiltransaksies teen } 14 / 11 \\
\text { ontvang) }\end{array}$ & 4 van die & vergoeding \\
\hline
\end{tabular}

Bron: Outeur se analise 
Veronderstel dieselfde gegewens as hierbo, behalwe dat gedurende jaar twee word al 100 myle by ' $n$ programvennoot ingeruil en voordele word ooreenkomstig gelewer. Die lugredery vergoed die programvennoot deur R90 (100 myle $\times$ R0.90) verskuldig te vereffen. TABEL 5 illustreer die rekeningkundige inskrywings van bogenoemde transaksie in die algemene joernaal van die lugredery.

TABEL 5: Algemene joernaalinskrywings van die lugredery

\begin{tabular}{|c|c|c|c|}
\hline Datum & Joernaalinskrywing & Debiet & Krediet \\
\hline \multirow[t]{5}{*}{ Jaar 1} & Bank $(1000 \times 1.14)$ & 1140 & \\
\hline & Inkomste uit die verkoop van dienste & & 900 \\
\hline & $\begin{array}{l}\text { Voorsiening vir die lewering van dienste / vir vergoeding } \\
\text { betaalbaar }\end{array}$ & & 100 \\
\hline & BTW-kontrole $(1140 \times 14 / 114)$ & & 140 \\
\hline & $\begin{array}{l}\text { (Verantwoord uitset-BTW op die oorspronklike verkooptrans } \\
\text { vergoeding ontvang) }\end{array}$ & ksie teen & 4 van die \\
\hline \multirow[t]{5}{*}{ Jaar 2} & $\begin{array}{l}\text { Voorsiening vir die lewering van dienste / vir vergoeding } \\
\text { betaalbaar }\end{array}$ & 100 & \\
\hline & BTW-kontrole $(90 \times 14 / 114)$ & 11.05 & \\
\hline & Bank & & 90 \\
\hline & Inkomste uit die verkoop van dienste & & 21.05 \\
\hline & $\begin{array}{l}\text { (Verantwoord inset-BTW teen } 14 / 114 \text { van die verg } \\
\text { programvennoot) }\end{array}$ & ding $b$ & aan die \\
\hline
\end{tabular}

Bron: Outeur se analise

\subsection{Voorbeeld: 'n Multivennootprogramtransaksie (Verpligting om voordele te lewer rus op die programvennoot alleen: Die verbruiker kan punte of myle slegs by'n programvennoot inruil)}

Vir doeleindes van die voorbeeld word slegs ' $n$ multivennootprogram waar ' $n$ verskeidenheid programvennote voorkom, geïllustreer. Komponent een van die transaksie vir beide tipes multivennootprogramme stem ooreen en gevolglik word ' $n$ multivennootprogram met ' $n$ enkele programeienaar nie geïllustreer nie (verwys na punt 8.4). Maatskappy A bestuur ' $n$ kliëntelojaliteitsprogram onafhanklik van enige van die programvennote binne ' $n$ multivennootprogram. Die programvennoot wat die punte toeken, moet maatskappy A R0.98 betaal vir elke punt toegeken. Wanneer ' $n$ programvennoot voordele lewer op grond van punte wat ingeruil word, sal die programvennoot R0.91 per punt ingeruil van maatskappy A ontvang. Maatskappy A se marge sal die verskil wees tussen R0.98 ontvang vir punte toegeken en die R0.91 betaal vir punte ingeruil. Gedurende jaar een is 1000 punte deur onderskeie programvennote toegeken en hierdie 1000 punte is ook by onderskeie programvennote ingeruil vir voordele. TABEL 6 illustreer die rekeningkundige inskrywings van bogenoemde transaksie in die algemene joernaal van maatskappy $A$. 
TABEL 6: Algemene joernaalinskrywings van maatskappy A

\begin{tabular}{|c|c|c|c|}
\hline Datum & Joernaalinskrywing & Debiet & Krediet \\
\hline \multirow[t]{8}{*}{ Jaar 1} & Bank & 980 & \\
\hline & Inkomste uit kliëntelojaliteitsprogramtransaksies & & 859.65 \\
\hline & BTW-kontrole $(980 \times 14 / 114)$ & & 120.35 \\
\hline & \multicolumn{3}{|c|}{$\begin{array}{l}\text { (Verantwoord uitset-BTW op die oorspronklike verkooptransaksie teen } 14 / 114 \text { van die } \\
\text { vergoeding ontvang) }\end{array}$} \\
\hline & Kliëntelojaliteitsprogramtransaksie-uitgawe & 798.25 & \\
\hline & BTW-kontrole $(910 \times 14 / 114)$ & 111.75 & \\
\hline & Bank & & 910 \\
\hline & $\begin{array}{l}\text { (Verantwoord inset BTW teen } 14 / 114 \text { van } \\
\text { programvennoot) }\end{array}$ & eding bet & aan die \\
\hline
\end{tabular}

Bron: Outeur se analise

\section{REKENINGKUNDIGE BENADERING VS. BELASTINGBENADERING}

' $n$ Suiwer rekeningkundige redenasie (gebaseer op IFRIC 13) met betrekking tot die verantwoording van ' $n$ kliëntelojaliteitsprogramtransaksie kan soos volg saamgevat word: Vergoeding word ontvang vir die lewering van goedere of dienste ingevolge die aanvanklike aankooptransaksie en vir die latere lewering van voordele wanneer punte of myle of kontantterugbewyse ingeruil word. BTW moet gevolglik slegs op hierdie aanvanklike vergoeding wat ontvang is, verantwoord word.

Dit is belangrik om te besef dat BTW deur middel van ' $n$ wet gehef word en dat die beginsels van die berekening van hierdie belasting gevolglik skriftelik weergegee moet word. Dit is slegs die $B T W$-wet wat geraadpleeg moet word om ' $n$ belastingpligtige se inset- en uitsetbelasting te bereken.

Ingevolge die BTW-wet word vergoeding nie net ingevolge die aanvanklike kliëntelojaliteitsprogram-aankooptransaksie ontvang nie, maar ook wanneer die punte of myle of kontantterugbewyse vir voordele ingeruil word. BTW moet gevolglik nie net soos die rekeningkundige redenasie voorstel slegs aanvanklik verantwoord word nie, maar ook wanneer punte of myle of kontantterugbewyse ingeruil word.

\section{RESULTAT\& EN BEVINDINGS VAN EMPIRIESE STUDIE}

Aanvanklik is ' $n$ populasie van 27 kliëntelojaliteitsprogramme geselekteer, gebaseer op die verslag soos deur Conradie (2007:1-283) saamgestel (verwys na punt 6 vir die seleksiekriteria van die populasie). Hierdie populasie van 27 kliëntelojaliteitsprogramme is verminder na 20 kliëntelojaliteitsprogramme ten einde alle finansiëledienstekliëntelojaliteitsprogramme in die Suid-Afrikaanse mark uit te sluit (verwys na punt 8.3). Twee gereelde vliegprogramme in die Suid-Afrikaanse mark wat slegs internasionale (nulkoers-) vlugte behartig, is ook van die 
omvang van die studie uitgesluit (verwys na punt 8.6, Uitgevoerde dienste: vervoer). Vraelyste is aan'n populasie van 18 programeienaars van kliëntelojaliteitsprogramme uitgestuur om te bepaal hoe programeienaars van kliëntelojaliteitsprogramme, kliëntelojaliteitsprogramtransaksies vir BTW-doeleindes hanteer.

Weens die aard van hierdie ondersoek was die formulering van die vrae baie belangrik. Dit moes vir die respondente maklik wees om die vrae te verstaan en te beantwoord ten einde die gewenste resultate te bereik. Ten einde alle onduidelikheid uit die weg te ruim, is die vraelys aan verskeie rekenmeesters gegee vir hersiening aangesien die respondente wat verantwoordelik sou wees om die vraelyste te voltooi oor ' $n$ rekeningkundige agtergrond beskik. Die vraelys is aan hierdie populasie van programeienaars van kliëntelojaliteitsprogramme gestuur en die respondente het een maand gehad om die vraelys te voltooi. Van die 18 respondente is 10 geldige antwoorde verkry, twee het geweier om deel te neem en die res het nie gereageer nie. Hierdie 10 respondente verteenwoordig ' $n$ responskoers van $56 \%$ en word geag verteenwoordigend te wees van programeienaars van kliëntelojaliteitsprogramme in SuidAfrika. Die data van die vraelyste is ontvang en verwerk.

\subsection{Respondenteprofiel}

Ten minste een respondent uit elke kategorie van kliëntelojaliteitsprogramme het op die vraelys gereageer. Die kategorie sowel as die aantal respondente word in TABEL 7 uiteengesit.

TABEL 7: Kategorie kliëntelojaliteitsprogram en ooreenstemmende aantal respondente

\begin{tabular}{cc}
\hline Kategorie & Aantal respondente \\
\hline Enkelmaatskappyprogram & 6 \\
Enkelmaatskappy-gedomineerde program & 1 \\
Multivennootprogram & 3 \\
\hline
\end{tabular}

Bron: Outeur se analise

\subsection{BTW-hantering van 'n kliëntelojaliteitsprogramtransaksie}

In die oorweging van die volgende vrae in die vraelys, aanvaar dat punte of myle of kontantterugbewyse nie vir basiese voedselsoorte ingeruil word nie. In die geval van gereelde vliegprogramme, aanvaar dat die dienste gelewer plaaslike vlugte verteenwoordig. In die geval van dobbelbedryfprogramme, aanvaar dat die punte ingeruil word op ' $n$ volgende weddenskap (en nie vir kontant nie) of vir goedere of dienste by 'n programvennoot. 
TABEL 8: Enkelmaatskappyprogram en enkelmaatskappy-gedomineerde program waar die programeienaar die voordele lewer

\begin{tabular}{cllcc}
\hline No. & Beskrywing & Ja & Nee \\
\hline 1 & $\begin{array}{l}\text { Uitsetbelasting word verantwoord op die oorspronklike } \\
\text { aankooptransaksie ingevolge waarvan punte of myle toegeken word } \\
\text { teen 14/114 van die vergoeding ontvang. }\end{array}$ & $100 \%$ & $0 \%$ \\
$2 \quad \begin{array}{l}\text { Uitsetbelasting word verantwoord wanneer punte of myle of } \\
\text { kontantterugbewyse ingeruil word teen 14/114 van die waarde van die } \\
\text { punte of myle of kontantterugbewyse ingeruil of die waarde van die } \\
\text { goedere of dienste gelewer. }\end{array}$ & $57 \%$ & $43 \%$ \\
\hline
\end{tabular}

Bron: Outeur se analise

Die korrekte / voorgestelde antwoord ingevolge die BTW-wet op vraag l is ' Ja, uitsetbelasting word verantwoord op die oorspronklike aankooptransaksie teen 14/114 van die vergoeding ontvang.' Alle respondente se antwoord op vraag 1 was 'Ja'. Die korrekte antwoord ingevolge die BTW-wet op vraag 2 is ' $\mathrm{Ja}$, uitsetbelasting word verantwoord wanneer punte of myle of kontantterugbewyse ingeruil word teen 14/114 van die waarde van die punte of myle of kontantterugbewyse ingeruil of die waarde van die goedere of dienste gelewer.' Respondente het verskillend gereageer op hierdie vraag. Dit is duidelik uit bogenoemde dat die BTW-wet nie in alle omstandighede in die praktyk korrek toegepas word nie. Sommige verskaffers verantwoord verkeerdelik nie vir uitsetbelasting ingevolge die tweede komponent van die kliëntelojaliteitsprogramtransaksie nie. Dit kan tot boetes en rente lei.

TABEL 9: Enkelmaatskappy-gedomineerde program waar 'n programvennoot die voordele lewer

\begin{tabular}{clcc}
\hline No. & \multicolumn{1}{c}{ Beskrywing } & Ja & Nee \\
\hline 1 & $\begin{array}{l}\text { Uitsetbelasting word verantwoord op die oorspronklike } \\
\text { aankooptransaksie ingevolge waarvan punte of myle toegeken word teen } \\
14 / 114 \text { van die vergoeding ontvang. }\end{array}$ & $100 \%$ & $0 \%$ \\
2 & $\begin{array}{l}\text { Insetbelasting word verantwoord op grond van die vergoeding wat aan } \\
\text { die programvennoot betaal is vir die lewering van die voordele teen } \\
14 / 114 \text { van die waarde van die vergoeding betal. }\end{array}$ & $100 \%$ & $0 \%$ \\
\hline
\end{tabular}

Bron: Outeur se analise

Die korrekte / voorgestelde antwoord ingevolge die BTW-wet op vraag l en vraag 2 is 'Ja', en die enkele respondent het albei vrae korrek beantwoord.

TABEL 10: Multivennootprogram met ' $n$ enkele programvennoot

\begin{tabular}{llcc} 
No. & \multicolumn{1}{c}{ Beskrywing } & Ja & Nee \\
\hline 1 & $\begin{array}{l}\text { Uitsetbelasting word verantwoord op grond van die vergoeding wat van } \\
\text { programvennote ontvang is vir die toekenning van punte of myle teen } \\
14 / 114 \text { van die vergoeding ontvang. }\end{array}$ & $100 \%$ & $0 \%$ \\
\hline
\end{tabular}

Bron: Outeur se analise 
Die korrekte / voorgestelde antwoord ingevolge die BTW-wet op vraag l is 'Ja', en die enkele respondent het hierdie vraag korrek beantwoord.

TABEL 11: Multivennootprogram met ' $n$ verskeidenheid programvennote

\begin{tabular}{cccc}
\hline No. & \multicolumn{1}{c}{ Beskrywing } & Ja & Nee \\
\hline 1 & $\begin{array}{l}\text { Uitsetbelasting word verantwoord op grond van die vergoeding wat van } \\
\text { programvennote ontvang is vir die toekenning van punte of myle teen } \\
\text { 14/114 van die vergoeding ontvang. }\end{array}$ & $50 \%$ & $50 \%$ \\
2 & $\begin{array}{l}\text { Insetbelasting word verantwoord op grond van die vergoeding wat aan } \\
\text { die programvennoot betaal is vir die lewering van die voordele teen } \\
14 / 114 \text { van die waarde van die vergoeding betaal. }\end{array}$ & $50 \%$ & $50 \%$ \\
\hline
\end{tabular}

Bron: Outeur se analise

Die korrekte / voorgestelde antwoord ingevolge die BTW-wet op beide vraag 1 en vraag 2 is ' $J a$ '. Vyftig persent van respondente het 'Nee' op vraag 1 en vraag 2 geantwoord. Dit is duidelik uit bogenoemde dat die BTW-wet nie in alle omstandighede in die praktyk korrek toegepas word nie. Sommige verskaffers verantwoord verkeerdelik nie vir uitsetbelasting op die eerste komponent van die transaksie nie, wat tot boetes en rente kan lei. Sommige verskaffers verantwoord verkeerdelik nie vir insetbelasting ingevolge die tweede komponent van die transaksie nie, wat sal lei tot ' $n$ kleiner bedrag wat die BTW-ondernemer by die SAID kan invorder en is gevolglik ' $n$ finansiële verlies.

\section{BESTUURSIMPLIKASIE}

Die resultate van die empiriese studie dui daarop dat verskaffers van kliëntelojaliteitsprogramme nie altyd die BTW-wet korrek interpreteer en toepas nie. Indien ' $n$ verskaffer (BTW-ondernemer) verkeerdelik nie uitsetbelasting verantwoord nie, sal hy in werklikheid die betaling van belasting ontduik, wat op ' $n$ misdryf dui en tot boetes, rente en selfs gevangenisstraf kan lei. Indien 'n verskaffer (BTW-ondernemer) verkeerdelik nie insetbelasting wat betaal is, verantwoord nie, sal dit tot ' $n$ kleiner bedrag lei wat die verskaffer van die SAID kan invorder en is gevolglik ' $n$ finansiële verlies. Dit is daarom baie belangrik dat verskaffers van kliëntelojaliteitsprogramme ' $n$ kliëntelojaliteitsprogramtransaksie vir BTW-doeleindes korrek verantwoord.

\section{GEVOLGTREKKING EN AANBEVELINGS}

Daar is bevind dat die SAID se leiding oor die BTW-hantering van ' $n$ kliëntelojaliteitsprogramtransaksie beperk is tot uitlegnota 41 wat slegs kliëntelojaliteitsprogramme in die dobbelbedryf insluit. Alle kliëntelojaliteitsprogramme wat ondersoek is, erken BTW op die faktuurbasis. Daar is ook bevind dat die twee komponente van ' $n$ kliëntelojaliteitsprogramtransaksie vir BTW-doeleindes as twee aparte transaksies hanteer moet word en dat die BTW implikasies vir elke kategorie kliëntelojaliteitsprogram verskil.

Vir ' $n$ enkelmaatskappyprogram en enkelmaatskappy-gedomineerde program waar die programeienaar die voordele lewer, sal die volgende vir die twee afsonderlike komponente van 
die kliëntelojaliteitsprogramtransaksie geld: Wanneer goedere of dienste ingevolge die oorspronklike kooptransaksie deur die programeienaar (BTW-ondernemer) gelewer word, moet $14 \%$-uitsetbelasting op die volle verkoopprys van hierdie goedere of dienste (die waarde van die punte of myle wat toegeken is, uitgesluit) gehef word en aan die SAID oorbetaal word. Wanneer punte of myle of kontantterugbewyse by die programeienaar ingeruil word, word vergoeding ontvang en moet die uitsetbelasting ingesluit in die vergoeding aan die SAID oorbetaal word.

Vir ' $n$ enkelmaatskappy-gedomineerde program waar ' $n$ programvennoot die voordele lewer, sal die volgende vir die twee afsonderlike komponente van die kliëntelojaliteitsprogramtransaksie geld: Wanneer goedere of dienste ingevolge die oorspronklike aankooptransaksie deur die programeienaar (BTW-ondernemer) gelewer word, moet 14\%-uitsetbelasting op die volle verkoopprys van hierdie goedere of dienste (die waarde van die punte of myle wat toegeken is, uitgesluit) gehef word en aan die SAID oorbetaal word. Wanneer punte of myle of kontantterugbewyse by die programvennoot (BTW-ondernemer) ingeruil word, betaal die programeienaar vergoeding (BTW ingesluit) aan die programvennoot. Die programeienaar kan die insetbelasting wat by die vergoeding ingesluit is van die SAID terugeis.

Vir ' $n$ multivennootprogram met ' $n$ enkele programvennoot sal die volgende vir die kliëntelojaliteitsprogramtransaksie geld: Wanneer punte of myle deur die programvennoot (BTW-ondernemer) toegeken word, moet die programeienaar (BTW-ondernemer) 14\%uitsetbelasting hef op die diens as fasiliteerder van die kliëntelojaliteitsprogram. Die programvennoot (BTW-ondernemer) sal vergoeding (BTW ingesluit) aan die programeienaar (BTW-ondernemer) betaal vir die toekenning van punte of myle en die programeienaar sal die uitsetbelasting aan die SAID moet oorbetaal.

Vir ' $n$ multivennootprogram met ' $n$ verskeidenheid programvennote sal die volgende vir die twee afsonderlike komponente van die kliëntelojaliteitsprogramtransaksie geld: Wanneer punte of myle deur die programvennoot (BTW-ondernemer) toegeken word, moet die programeienaar (BTW-ondernemer) 14\%-uitsetbelasting hef op die diens as fasiliteerder van die kliëntelojaliteitsprogram. Die programvennoot (BTW-ondernemer) sal vergoeding (BTW ingesluit) aan die programeienaar (BTW-ondernemer) betaal vir die toekenning van punte of myle en die programeienaar sal die uitsetbelasting aan die SAID moet oorbetaal. Wanneer punte of myle of kontantterugbewyse by die programvennoot (BTW-ondernemer) ingeruil word, betaal die programeienaar vergoeding (BTW ingesluit) aan die programvennoot. Die programeienaar kan die insetbelasting wat by die vergoeding ingesluit is van die SAID terugeis.

Gegewe die resultate van die navorsing kan 'n algemene gevolgtrekking gemaak word dat daar leemtes bestaan in die interpretasie en toepassing van die BTW-wet ten opsigte van kliëntelojaliteitsprogramtransaksies in Suid-Afrika. ' $n$ Gebrek aan leiding van die SAID bestaan met betrekking tot die hantering van kliëntelojaliteitsprogramtransaksies wat dringend aandag vereis. Daar word voorgestel dat die SAID riglyne moet formuleer ten opsigte van die BTWhantering van kliëntelojaliteitsprogramtransaksies in die hande van ' $n$ programeienaar ten einde die korrekte en konsekwente interpretasie en toepassing van die BTW-wet te verseker. Hierdie artikel het beginsels uitgelig wat die verwarring oor die BTW-hantering van kliëntelojaliteitsprogramtransaksies uit die oogpunt van die verskaffer moontlik kan opklaar. Hierdie inligting kan dus as ' $n$ nuttige hulpmiddel dien vir rolspelers in die Suid-Afrikaanse belastingomgewing wanneer bostaande aangeleentheid na vore tree. 


\section{BronNelyS}

Andoh, C. (2008). Business-financed employee voyager-mile points earned from SAA-a taxable benefit? Ongepubliseerde meestersverhandeling. Pretoria: Universiteit van Pretoria.

Beneke, C. (2012). Discounts and the determination of value. Deloitte and Touche VAT Handbook. [Intyds].

Beskikbaar: http://www.lib.sun.ac.za.ez.sun.ac.za/nxt/gateway/dll?f=templates $\$ f n=$ default.htm $\$ v i$ $\mathrm{d}=$ mylnb:10.1048/enu. [30 Augustus 2012].

Beneke, C. (2012). Acceptance of, and winnings from, a bet. Deloitte and Touche VAT Handbook. [Intyds] Beskikbaar: http://www.lib.sun.ac.za.ez.sun.ac.za/nxt/gateway.dll?f=templat es $\$ f n=$ default.htm $\$ v i d=m y l n b: 10.1048 /$ enu. [30 Augustus 2012].

Brink, S.M. \& Viviers, H. (2012). Inkomstebelastinghantering van kliëntelojaliteitsprogramtransaksies in Suid-Afrika. Journal of Economic and Financial Sciences, 5(2), pp. 437-458.

Brink, S.M. (2013). The accounting treatment of single company client loyalty programme transactions. Journal of Economic and Financial Sciences, 6(3), pp.797-816.

Clegg, D. (2002). Voyager miles - taxable fringe benefit? Tax Planning: Corporate and Personal, $16(2): 33-35$.

Commissioner for HMRC v Total Limited Court of Appeal [2007] ENHC 342

Conradie, B. (bruce@worldwideworx.com). 17 Junie 2011. RE: Bruce Conradie. $\varepsilon$-pos aan die outeur.

Conradie, B. (2007). Value in loyalty programmes 2007: A survey of South African rewards-based loyalty programmes. Razor's Edge Business Intelligence.

Conradie, B. \& Goldstuck, A. (2005). Value in loyalty programmes 2005: A survey of South African rewards-based loyalty programmes. Razor's Edge Business Intelligence World Wide Worx.

Conradie, B. \& Goldstuck, A. (2003). Value in loyalty programmes 2003: A survey of South African rewards-based loyalty programmes. Razor's Edge Business Intelligence World Wide Worx.

IAS 18, Revenue. (1993). International Accounting Standards Board (IASB). London.

IFRIC 13, Customer Loyalty Programmes. (2007). International Accounting Standards Board (IASB). London.

Jones, S. (2009). Taxing frequent-flyer miles. TaxBreaksNewsletter, 285(10), pp. 1-2. [Intyds] Beskikbaar: http://search.sabinet.co.za.ez.sun.ac.za/WebZ/images/ejour/ montb/montb_n285_al.pdf?sessionid=01-59014-263192708\&format=F. [6 Julie 2010].

Liu, Y. (2007). The long-term impact of loyalty programs on consumer purchase behaviour and loyalty. Journal of Marketing, 71, pp. 19-35. [Intyds] Beskikbaar: http://web.ebscohost.com.ez.sun.ac.za/ehost/pdfviewer/pdfviewer?sid=eb9lde90-b5da-4e0fbb71-4a9965cla313\%40sessionmgrl1\&vid=5\&hid=17. [19 April 2011].

Maharaj, A. (2008). Awareness perceptions and effects of customer loyalty programmes within the retail sector of the Durban Metropolitan area. Ongepubliseerde meestersverhandeling. Suid-Afrika: Universiteit van Suid-Afrika.

Pretorius, L. (2010). An analysis of the employees' tax implications of loyalty points awarded to employees in South Africa. Ongepubliseerde meestersverhandeling. Pretoria: Universiteit van Pretoria. 
PricewaterhouseCoopers. (2009). Making sense of a complex world IFRIC 13 - Customer loyalty programmes [Intyds]. Beskikbaar: http://www.pwc.com/en_GX/gx/communications/ pdf/IFRIC13.pdf. [11 Mei 2012].

Republiek van Suid-Afrika. (1991). Wet op Belasting op Toegevoegde Waarde no. 89 van 1991. Pretoria: Staatsdrukkery.

Republiek van Suid-Afrika. (2008). Wet op Verbruikersbeskerming No. 68 van 2008. Kaapstad: Staatskoerant 526 (32186):1-94.

Rowley, J. (2005). Customer relationship management through the Tesco Clubcard loyalty scheme. International Journal of Retail \& Distribution Management, 33(3), pp. 194-206.

South African Revenue Service. (2008). Interpretation note No. 41 (Edition 2)

South African Revenue Service. (2007). Interpretation note No. 4 l (Edition 1)

Stiglingh, M., Koekemoer, A.D., Van Schalkwyk, L., Wilcocks, J.S. \& De Swardt, R.D. (2012). S/LKE: SuidAfrikaanse Inkomstebelasting 2012. Durban: LexisNexis.

Travel wires. (2011). 'Terms and conditions' distort loyalty programmes - Protea Hospitality. [Intyds] Beskikbaar: http://www.travelwires.com/wp/2011/03/\%ع2\%80\%9Ctermsconditions\%E2\%80\%9D-distort/. [8 April 2011]. 
